\title{
SOUTH PACIFIC CLEISTOCALYX TRANSFERRED TO SYZYGIUM (MYRTACEAE)
}

\author{
E. BIFFIN ${ }^{1,2}$, L.A. CRAVEN ${ }^{1}$, M. TUIWAWA ${ }^{3}$, M.D. CRISP ${ }^{2} \&$ P.A. GADEK ${ }^{4}$
}

\begin{abstract}
SUMMARY
Evidence from both morphological and molecular phylogenetic data support the view that the circumscissile calycine calyptra, the sole defining character of Cleistocalyx, has multiple origins within Syzygium s.l. and is therefore an invalid basis for generic circumscription. Accordingly, the Fijian Cleistocalyx are transferred to Syzygium, and the new combinations Syzygium decussatus, S. eugenioides and S. seemannii, are made. Syzygium myrtoides is reinstated, and Cleistocalyx ellipticus, C. longiflorus, $C$. kasiensis and $C$. seemannii var. punctatus are reduced to the synonymy of $S$. seemannii. The distribution of $S$. seemannii is extended to Vanuatu.
\end{abstract}

Key words: Acicalyptus, Cleistocalyx, Syzygium, Myrtaceae, molecular phylogeny, morphology.

\section{INTRODUCTION}

As part of our ongoing studies into relationships within Syzygium Gaertn. s. 1., we have had the opportunity to examine members of the group from the south western Pacific region, including Fiji, New Caledonia and Vanuatu. Of particular interest is the status of several Fijian taxa, which are presently referred to Blume's genus Cleistocalyx (Smith, 1985). Cleistocalyx Blume is one of several proposed, and variously accepted, segregates from Syzygium s.1., such as Acmena DC., Acmenosperma Kausel, Piliocalyx Brongn. \& Gris and Waterhousea B. Hyland. Generic circumscription within Syzygium s.1. has long been considered contentious (e.g. Merrill \& Perry, 1939; Henderson, 1949; Schmid, 1972; Hyland, 1983; Smith, 1985; Craven, 2001) and this is particularly true with respect to Cleistocalyx. Amongst recent treatments, Cleistocalyx is accepted by Merrill \& Perry (1937), Briggs \& Johnson (1979), Kostermans (1981), Smith (1985) and Chantaranothai \& Parnell (1994), but not by Schmid (1972), Hyland (1983), Craven (1998) or Dawson (1999).

Given that, of the 500 to 1000 species included in Syzygium s.l., somewhere in the vicinity of $5 \%$ posses a calycine calyptra, this is clearly a valuable character for taxonomic purposes. However, the Cleistocalyx group is not clearly distinguished from Syzygium s. str. by floral anatomy (Schmid, 1972), wood anatomy (Ingle \& Dadswell, 1953) or pollen morphology (Pike, 1956); nor did Merrill \& Perry (1937), Briggs \& Johnson (1979) or Smith (1985) mention any vegetative or fruit characters by which

1) Australian National Herbarium, CPBR, CSIRO Plant Industry, G.P.O. Box 1600, Canberra, ACT 2601, Australia.

2) Division of Botany and Zoology, Australian National University, Canberra, ACT 2601, Australia.

3) South Pacific Regional Herbarium, University of the South Pacific, Suva, Fiji.

4) School of Tropical Biology, James Cook University, Cairns, Queensland, 4870, Australia. 
the group could be consistently distinguished. In the absence of corroborative evidence from related disciplines, the circumscription of Cleistocalyx rests entirely upon a single constant character, the possession of a circumscissile calycine calyptra.

In his treatment of the Australian species of Syzygium s.1., Hyland (1983) reduced the three Australian Cleistocalyx to Syzygium, in belief that if the calycine calyptra was excluded from consideration, these plants were not representatives of the same evolutionary lineage. With similar reasoning, Craven (1998) transferred the Lord Howe Island endemic species Cleistocalyx fullagarii (F. Muell.) Merr. \& L.M. Perry to Syzygium. While not specifically stating their position, both Dawson (1999; 4 New Caledonian species) and Takeuchi (2002; 2 Papuasian species) preferred Syzygium rather than Cleistocalyx, as the correct generic placement for calyptrate syzygioid taxa. Of the remaining calyptrate species in the eastern Malesian region, several have been referred to Piliocalyx (which has affinities with Acmena rather than Syzygium) and will not be further considered here, but the seven Fijian species presently included in Cleistocalyx, together with a calyptrate plant from Vanuatu, are discussed below.

In Smith's $(1971,1985)$ treatments of the Fijian Syzygium s.1., he notes that while sterile and fruiting specimens of Cleistocalyx require close scrutiny for correct identification, the buds and flowers are strikingly distinct, and that we may equally question the distinctiveness of Syzygium (from Eugenia L.) and Acmena (from Syzygium s. str.) as Cleistocalyx. The Fijian Cleistocalyx, along with the Vanuatu collections, are reasonably distinctive, and are almost certainly closely related, and this distinctiveness presumably prompted Gray's erection of the genus Acicalyptus to accommodate two Fijian species (Gray, 1854, 1862), and Merrill \& Perry's (1937) maintenance of Acicalyptus as a section of Cleistocalyx for 5 Fijian taxa. Even with respect to floral morphology, however, the Fijian taxa share little in common with other calyptrate species within the region. For example, the Fijian Cleistocalyx have a condensed axile-central placenta, on which the ovules are 'scattered', basally attached and radiating to ascending. The calyptrate species from New Caledonia, and S. fullagarii, have considerably larger flowers, with pendulous, laterally attached, biseriate ovules. The Australian calyptrate species $S$. gustavioides B. Hyland has an axile-central placenta on which the ovules are pendulous and laterally attached. Variation in ovule orientation and placental structure has been considered phylogenetically significant in Syzygium s.1. (e.g. Hyland, 1983; Craven, 2001) and other fleshy fruited Myrtaceae (e.g. Eugenia L., Van Wyk \& Botha, 1984) and may be more indicative of relationships in Syzygium s. 1. than is the presence/absence of a calycine calyptra. The shape of the ovules per se may also be significant and this is currently being evaluated.

Recent molecular systematic studies have provided additional insight into the status of Cleistocalyx. Harrington \& Gadek (2004) sampled 66 Australasian species of Syzygium s.1., including the calyptrate taxa $S$. gustavioides (F.M. Bailey) B. Hyland, S. nervosum DC., S. canicortex B. Hyland and S. fullagarii (F. Muell.) Craven, for sequences of the ITS and ETS regions of nuclear ribosomal DNA. With respect to Cleistocalyx, the results of this study are consistent with the views of Hyland (1983) and Craven (1998). Syzygium canicortex and S. fullagarii are resolved (but not as sister taxa) in a strongly supported group along with several Syzygium species and Acmenosperma (A. claviflorum (Roxb.) Kausel), S. nervosum occurs in a separate, strongly supported clade of predominantly syzygioid taxa, and the relationships of $S$. gustavioides are unresolved. 
Using DNA sequences from the chloroplast regions $m a t K, n d h F$ and the rpll6 intron, Biffin et al. (in review) have developed a molecular data set for a geographically broad sample of Syzygium s.1. In addition to the species mentioned above, these data include representatives of the Fijian Cleistocalyx group (C. longiflorus (A.C. Sm.) Merr. \& L.M. Perry, C. ellipticus (A.C. Sm.) Merr. \& L.M. Perry, C. decussatus A.C. Sm.) and the New Caledonian calyptrate taxon S. kuebiniense J.W. Dawson. These data provide strong support (i.e. bootstrap $=90 \%$ ) for 4 major lineages within Syzygium s. 1., three of which include taxa that are referable to Cleistocalyx. Even within these groups, there is evidence for multiple origins of the calycine calyptra, and while the Fijian Cleistocalyx form a robust, monophyletic group, their close relationships appear to rest with typically syzygioid species rather than other calyptrate taxa. Their analyses include other Fijian Syzygium species (S. amplifolium L.M. Perry, S. brackenridgei (A. Gray) C. Muell., S. gracilipes (A. Gray) Merr. \& L.M. Perry, S. purpureum (L.M. Perry) A.C. Sm., S. seemanianum Merr. \& L.M. Perry) which are resolved in the same major clade as the three Fijian Cleistocalyx although not as sister taxa (Biffin et al., in review). From this we conclude that the Fijian syzygioid species probably have diverse evolutionary origins.

Both morphological and molecular evidence supports the view that Cleistocalyx, as presently circumscribed, is a polyphyletic assemblage and should not be maintained at generic level. The Fijian Cleistocalyx, and the material from Vanuatu, are best included in Syzygium, consistent with the treatment of other calyptrate syzygioid taxa within the eastern Malesian region. Ultimately, if recent arguments for an inclusive concept of Syzygium s. 1. (Craven, 2001, 2003; Craven \& Biffin, 2005) are borne out by accumulating morphological and molecular evidence, this placement is in the interest of taxonomic stability of the group. Accordingly, the Fijian Cleistocalyx species below are transferred to Syzygium.

Insofar as the tree flora of Fiji is concerned, Syzygium (incl. Cleistocalyx) provides particular difficulties for those conducting biodiversity and floristic studies. Contemporarily collected specimens are difficult to equate to the species as Smith (1985) delimited them. Because Syzygium species are common components of the Fijian rainforests, it is important that unambiguous identifications are made. The opportunity has been taken to consider the species limits of the Fijian representatives of Cleistocalyx as part of the present investigations into their generic affiliations. We suggest that four species only should be recognised in lieu of the seven accepted by Smith (1985), and in the enumeration below several novel reductions have been effected.

\section{Syzygium decussatum (A.C. Sm.) Biffin \& Craven, comb. nov.}

Basionym: Cleistocalyx decussatus A.C. Sm. (1971) 495. - Type: DF 310 (I. Bola 108) (holo BISH n.v.; iso K, SUVA), Fiji, Viti Levu, Naitasiri Province, Colo-i-suva, 22 Feb. 1962.

\section{Syzygium eugenioides (Merr. \& L.M. Perry) Biffin \& Craven, comb. nov.}

Basionym: Cleistocalyx eugenioides Merr. \& L.M. Perry (1937) 330. - Calyptranthes eugenioides Seem. (1866) 81, nom illeg., non Cambess. (1833). - Type: Seemann 156 (holo K; iso GH), Fiji, Viti Levu, without further locality, 1860. 


\section{Syzygium myrtoides (A. Gray) R. Schmid}

Syzygium myrtoides (A. Gray) R. Schmid (1972) 478. - Acicalyptus myrtoides A. Gray (1854) 551, t. 67. - Calyptranthes myrtoides (A. Gray) Seem. (1866) 81. - Cleistocalyx myrtoides (A. Gray) Merr. \& L.M. Perry (1937) 329. - Type: U.S. Expl. Exped. 1838-42 (holo US n.v., image seen; iso GH, K), Fiji, Vanua Levu, mountains of Macuata Province, 1840.

\section{Syzygium seemannii (A. Gray) Biffin \& Craven, comb. nov.}

Basionym: Acicalyptus seemanni A. Gray (1862) 317. - Calyptranthes seemanni (A. Gray) Seem. (1866) 81. - Cleistocalyx seemanni (A. Gray) Merr. \& L.M. Perry (1937) 330. - Type: Seemann 168 (holo GH; iso BM n.v., K), Fiji, Vanua Levu, the coast of Macuata Province, 1860. (See note 3.)

Eugenia prora Burkill (1906) 4. - Type: Yeoward 41 (lecto (fide Smith (1985) 363) K), Fiji, without further locality, Nov. 1894.

Cleistocalyx seemanni (A. Gray) Merr. \& L.M. Perry var. punctatus Merr. \& L.M. Perry (1937) 330. - Type: Graeffe (holo GH; iso K), Macuata Province, Mt Tana Lailai, Ovalau, Dec. 1864.

Acicalyptus elliptica A.C. Sm. (1936) 107, f. 57a, c. - Cleistocalyx ellipticus (A.C. Sm.) Merr. \& L.M. Perry (1937) 330. - Type: Smith 1567 (holo BISH n.v.; iso GH, K), Fiji, Vanua Levu, Bua Province, Seatovo Range, 20 Apr. 1934.

Acicalyptus longiflora A.C. Sm. (1936) 109, f. 57d. - Cleistocalyx longiflorus (A.C. Sm.) Merr. \& L.M. Perry (1937) 329. - Type: Storck XXV or XXVI (holo K; iso GH), Fiji, without further locality, June 1883.

Cleistocalyx kasiensis A.C. Sm. (1971) 495. - Type: DA 15740 (leg. E. Damanu) (holo BISH n.v.; iso K), Fiji, Vanua Levu, Cakaudrove Province, Mt Kasi area, 7 June 1968.

Notes - 1. Smith (1985) chose to recognise C. ellipticus, C. longiflorus and C. kasiensis at specific level and, 'without much conviction' (p. 364), maintained Merrill \& Perry's (1937) var. punctatus within C. seemannii. With respect to the latter, we note that some specimens (e.g. Gillespie 2866, Horne 774, Yeoward 41) are intermediate in terms of prominence, and density of glands, reducing the value of this separation. In rejecting Gray's genus Acicalyptus, Smith (1985: 359) notes that flower size, elongate calycine calyptra, and bud- and fruit- angularity are characters usable only at specific level, and there, not easily (emphasis added). He then uses bud- and fruit-angularity and flower size to separate $C$. ellipticus and $C$. longiflorus, although there are no marked discontinuities in the characters above. In our opinion, these characters represent a continuum, as does leaf size, and the development of an acumen. If these are excluded from consideration, $C$. ellipticus may be distinguished (but not consistently) from C. longiflorus by its ultimate inflorescence branchlets, with flowers in triads, compared with usually solitary flowers, but not from $C$. seemannii or $C$. kasiensis, in which the former condition predominates. Cleistocalyx kasiensis, known only from the type collection, is distinguished only by its shortly petiolate leaves, which again may be regarded as an outlier in what is essentially a continuum. The petiole in $C$. seemannii, C. longiflorus and C. ellipticus is 2-11,3-10 and 6-15 mm long, respectively, whereas in C. kasiensis it is $2 \mathrm{~mm}$ long. Given that the leaf blades (including acumen) of $C$. kasiensis in shape are consistent with the variation occurring in the three former taxa, the differences in petiole length between $C$. kasiensis and $C$. longiflorus and $C$. ellipticus are an inadequate foundation upon which to base a species.

2. Several specimens from Vanuatu also fall within our concept of S. seemannii. We note that just prior to anthesis, the buds of the Vanuatuan plant are larger (5-7 mm 
long) than in the Fijian material we have seen, and the hypanthium is swollen at the apex beyond that which is typical for S. seemannii. In other respects, the specimens from Vanuatu are a good match for $C$. seemannii sensu Smith, and key out to this taxon in his flora (Smith, 1985). These specimens thus extend the range of S. seemannii to Vanuatu. The relevant details of the Vanuatuan collections are: Morrison s.n., Aneityum, peak S of Ithumu, tree c. $19 \mathrm{ft}$., 30 June 1890 (K); Morrison s.n., Aneityum, peak S of Ithumu, alt. 1835 ft., tree c. 20 ft., 30 June 1890 (K); Morrison s.n., Aneityum, summit of peak (2300 ft.) between Anumy and Ithug, 26 June 1896 (K, 2 sheets).

3. It appears that the locality from which the type collection of A. seemanni, Seemann 168, was made is uncertain. Smith drew attention to the fact that the locality, Port Kinnaird, Ovalau, [Lomaiviti Province,] is given on the isotype material at K (Smith, 1985). Seemann, however, cites the Macuata locality given above (Seemann, 1866).

\section{ACKNOWLEDGEMENTS}

The Directors and/or Curators of the following herbaria are thanked for providing access to collections in their care: A, BISH, CANB, GH, K, SUVA. The following are thanked for their generosity and assistance during fieldwork in Fiji: Alifereti Naikatini, Isaac Rounds, Mosese Moceyawa. Field work in Fiji was made possible through a grant from the Pacific Biological Foundation. Ed Biffin holds an ABRS Postgraduate Scholarship from the Australian Biological Resources Study, and a Scholarship from the Australian National University. This support is gratefully acknowledged.

\section{REFERENCES}

Biffin, E., L.A. Craven, M.D. Crisp \& P.A. Gadek. In review. Molecular systematics of Syzygium and allied genera (Myrtaceae): evidence from the chloroplast genome.

Briggs, B.G. \& L.A.S. Johnson. 1979. Evolution in the Myrtaceae - evidence from inflorescence structure. Proc. Linn. Soc. New South Wales 102: 157-256.

Burkill, I.H. 1906. Eugenia prora. Kew Bull. 1906: 4.

Cambessèdes, J. 1833. Calyptranthes eugenioides. In: A.F.C.P. de Saint-Hilaire, J. Cambessèdes \& A.H.L. de Jussieu, Flora Brasiliae meridionalis. Vol. 2: 370.

Chantaranothai, P. \& J. Parnell. 1994. A revision of Acmena, Cleistocalyx, Eugenia s.s. and Syzygium (Myrtaceae) in Thailand. Thai Forest Bull., Bot. 21: 1-123.

Craven, L.A. 1998. Cleistocalyx fullagarii transferred to Syzygium (Myrtaceae). Muelleria 11: 95-96.

Craven, L.A. 2001. Unravelling knots or plaiting rope: What are the major taxonomic strands in Syzygium sens. lat. (Myrtaceae) and what should be done with them? In: L.G. Saw, L.S. L. Chua \& K. C. Khoo, Taxonomy: the cornerstone of biodiversity. Proc. Fourth Fl. Males. Symp.: 75-85. Inst. Pen. Perhutanan Malaysia, Kuala Lumpur.

Craven, L.A. 2003. Four new species of Syzygium (Myrtaceae) from Australia. Blumea 48: 479-488.

Craven, L.A. \& E. Biffin. 2005. Anetholea anisata transferred to, and two new Australian taxa of, Syzygium (Myrtaceae). Blumea 50: 157-162.

Dawson, J.W. 1999. Myrtaceae. Myrtoideae I: Syzygium. In: Ph. Morat (ed.), Fl. Nouvelle-Calédonie Vol. 23. Muséum National d'Histoire Naturelle, Paris.

Gray, A. 1854. Acicalyptus. U.S. Expl. Exped., Atlas Phan. 1: 551-553, t. 67.

Gray, A. 1862. Notes upon a portion of Dr. Seemann's recent collection of dried plants gathered in the Feejee Islands. Proc. Amer. Acad. Arts 5: 314-321.

Harrington, M. G. \& P. A. Gadek. 2004. Molecular systematics of the Acmena alliance (Myrtaceae): phylogenetic analyses and evolutionary implications with reference to Australian taxa. Austral. Syst. Bot. 17: 63-72. 
Henderson, M.R. 1949. The genus Eugenia (Myrtaceae) in Malaya. Gard. Bull. Singapore 12: $1-293$.

Hyland, B.P.M. 1983. A revision of Syzygium and allied genera (Myrtaceae) in Australia. Austral. J. Bot., Suppl. 9: 1-164.

Ingle, H.D. \& H.E. Dadswell. 1953. The anatomy of timbers of the south-west Pacific area. III. Myrtaceae. Austral. J. Bot. 1: 353-401.

Kostermans, A.J.G.H. 1981. Eugenia, Syzygium and Cleistocalyx (Myrtaceae) in Ceylon. A monographical revision. Quart. J. Taiwan Mus. 34: 117-188.

Merrill, E.D. \& L.M. Perry. 1937. Reinstatement and revision of Cleistocalyx Blume (including Acicalyptus A. Gray), a valid genus of the Myrtaceae. J. Arnold Arbor. 18: 322-343.

Merrill, E.D. \& L.M. Perry. 1939. The myrtaceous genus Syzygium Gaertner in Borneo. Mem. Amer. Acad. Arts 18: 135-202.

Pike, K. 1956. Pollen morphology of Myrtaceae from the south-west Pacific area. Austral. J. Bot. 4: $13-15$.

Schmid, R. 1972. Floral morphology of Myrtaceae. I. Bot. Jahrb. Syst. 92: 433-489.

Seemann, B. 1866. Myrtaceae. Fl. Vit.: 76-84, t. 15, 16.

Smith, A.C. 1936. Myrtaceae. Fijian Plant Studies. Bernice P. Bishop Mus. Bull. 141: 105-111.

Smith, A.C. 1971. Studies of Pacific plants, XXII. New flowering plants from Fiji. Pacific Sci. 25: 491-501.

Smith, A.C. 1985. Syzygium and Cleistocalyx. Fl. Vit. Nova 3: 313-368. Pacific Tropical Botanical Garden, Lawai, Hawaii.

Takeuchi, W. 2002. Notes and new species in Papuasian Syzygium (Myrtaceae). Edinburgh J. Bot. 59: $259-272$.

Van Wyk, A.E. \& R. Botha. 1984. The genus Eugenia L. (Myrtaceae) in Southern Africa: Ontogeny and taxonomic value of the seed. S. African J. Bot. 3: 63-80. 